\title{
E-Readiness Status of Primary Schools Implementing Digital Devices in Kisii County
}

\author{
https://doi.org/10.3991/ijes.v8i1.12567 \\ Makworo Edwin Obwoge ${ }^{(\varpi)}$, Abuya Teresa Kwamboka \\ Kisii University, Kisii, Kenya \\ edwinax2000@kisiiuniversity.ac.ke \\ Nyakoe George Morara \\ Kisii National Polytechnic, Kisii, Kenya
}

\begin{abstract}
Delivery of education content to learners in many learning environments has greatly been enhanced by the deployment and implementation of Information Communication Technologies (ICTs) in the world today. Many developing countries are putting in place strategies to ensure their education systems use ICT to improve and diversify learning to meet the global changes in technology. In Kenya, ICT Integration in Primary Education is one of the key flagship programmes that has received keen attention by the government in the past few years through the primary schools Digital Literacy Programme (DLP). This research endeavoured to establish the e-readiness of primary schools implementing use of digital devices in Kisii County. Survey research design was applied in the study. The population of the study constituted of 710 primary school head teachers, 1,420 standard one and two teachers and 71,000 standard one and two pupils. Sample size was determined using the fisher formula and the sample consisted of 249 primary school head teachers, 302 standard one and two teachers and 381 standard one and two pupils. Purposive sampling was used to select schools, head teachers and teachers. Simple random sampling was used to select the specific schools to include in the study and proportionate sampling was used to determine the number of respondents from each school. The research instruments applied in the research included self-administered questionnaires for teachers and head teachers and interview schedules for pupils. To ascertain the reliability of the research instruments, a pilot test was carried out and a Cronbach's alpha coefficient of 0.76 was realized. Data was analysed qualitatively and quantitatively using descriptive statistics in SPSS.The research established that the main impediment to implementation of the DLP was the psychological and financial readiness within the schools. There should be a well planned training schedule for teachers and a budget be put in place for the primary schools for the DLP.
\end{abstract}

Keywords - Digital Literacy Programme, Information Communication Technology, E-readiness 


\section{Background}

Digital and ICT literacy is considered an important competence for full participation in a knowledge economy and an information society. Information and communications technologies (ICTs) have become pervasive in modern societies as tools for transforming education systems, supporting economic development through the creation of new products and services, providing access to information and expertise to support improvements in agriculture, health and education, and connecting communities, teachers and students. Many learning institutions have embraced and continue to reap the benefits of using various ICT technologies in the teaching learning process. ICT provides teachers and students with the resources to collect and analyze data, create multimedia presentations and acquire greater depth of knowledge. Integration of ICT across all levels of subjects and education is envisaged to enhance 21st Century learning skills among others.

Kenya's vision 2030 programme recognizes the value of Information Communication Technology (ICT) in its growth to a rapidly industrializing economy by the year 2030. One of the vision 2030 flagship projects for education and training was to establish a computer supply programme that was to equip students with modern IT skills and align integration of ICT into teaching and learning. It is with this in mind that the Kenya government launched the Digital Learning Programme (DLP) for all primary schools. The digital literacy programme was a programme borne out of the government of Kenya's vision to make sure every pupil is prepared for today's digital world, and to transform learning in Kenya into a 21st century education system. The benefits that e-learning brings to an educational institution in today's technological world cannot be underestimated. Its therefore very important that educational institutions in developing countries embrace and give it a priority.

E-learning is the delivery of course content through electronic means which include computer-based learning, online learning and distance education [4]. Elearning is the integration of modern technology into the classrooms which can sometimes include learning that is completely independent of mediation [17]. The biggest domains of the users of e-learning are schools, colleges and universities which have paid special attention to e-learning in order to expedite the learning procedures [14]. Educators are increasingly aware of the potential and practicalities of using computer assisted learning in the primary classroom and in many circumstances have adopted it as just another pedagogy [12].

All learning experiences are unproven until they have been thoroughly evaluated well before they could be judged as reliable, appropriate or even adequate for children [16]. In order to benefit from e-learning it is necessary to consider up-front analysis to assess the readiness of prospective e-learning implementation [1, 15]. E-learning readiness is "the mental or physical preparedness of an organization for some elearning experience or action" [5]. E-Learning readiness assessment helps an organization to design e-learning strategies comprehensively and to implement its ICT goals effectively [10]. A model for measuring the e-learning readiness of an organisation that groups different factors into eight categories was designed by [7]. 
- Psychological readiness. This factor considers the individual's state of mind as it impacts the outcome of the e-learning initiative. This is considered one of the most important factors and has the highest possibility of sabotaging the implementation process.

- Sociological readiness. This factor considers the interpersonal aspects of the environment in which the program will be implemented.

- Environmental readiness. This factor considers the large-scale forces operating on the stakeholders both inside and outside the organization.

- Human resource readiness. This factor considers the availability and design of the human-support system.

- Financial readiness. This factor considers the budget size and allocation process.

- Technological skill (aptitude) readiness. This factor considers observable and measurable technical competencies.

- Equipment readiness. This factor considers the question of the proper equipment possession.

- Content readiness. This factor considers the subject matter and goals of the instruction.

It is upon this model that the e-readiness of primary schools implementing digital learning devices in Kisii County was assessed.

\section{Objective of the Study}

The main objective of the study was to establish the e-readiness status of primary schools implementing the use of teacher and learner digital devices in Kisii County.

\section{$3 \quad$ Methodology}

\subsection{Research design}

The research design directs the research activities to ensure that valid conclusions are attained [8]. As described by [8] research design is a planned framework for action that serves as a connection between research questions and the execution or implementation of the research. The research applied survey research design. A survey is an attempt to collect data from members of a population in order to determine the current status of that population with respect to one or more variables [13]. Survey design was chosen because it's economical and has a rapid turn-around in data collection. It also has the advantage of identifying attributes of a large population from a small group of individuals [2,9]. 


\subsection{Population}

The population of the study constituted of 710 primary school head teachers, 1,420 standard one and two teachers and 71,000 standard one and two pupils.

\subsection{Sample size determination}

Sample size was determined using the fisher formula:

$$
\mathrm{n}=\frac{z^{2} p(1-p)}{\delta^{2}}
$$

Where; z -Statistical constant (1.96)

$\mathrm{P}$ - Prevalence of undetermined population (0.5)

$\delta$ - Error of margin (0.05)

After substitution, $\mathrm{n}=384.16(\sim 384)$

Using the finite population correction factor

$$
\mathrm{n}_{1}=\frac{n}{1+\frac{n}{N}}
$$

The sample sizes were as follows; 249 primary school head teachers, 302 standard one and two teachers and 381 standard one and two pupils

\subsection{Sampling procedures}

Purposive sampling was used to select schools that have already implemented the Digital Literacy Programme, the head teachers and teachers. Simple random sampling was used to select the specific schools to include in the study and proportionate sampling was used to determine the number of respondents from each school.

\subsection{Research instruments}

Three research instruments were applied in this research; self-administered questionnaires, interview schedules and observation schedules. According to [13], a self-administered questionnaire is one in which respondents complete the questionnaires themselves. According to [2], survey research can apply questionnaires or structured interviews for data collection. The self-administered questionnaires were applied in collecting data from teachers and head teachers while the interview schedules and observation schedules were used for pupils.

\subsection{Reliability}

To establish the reliability of the research instruments a pilot-test was carried out in three primary schools in Nyamira County and the Cronbach's alpha wasused to measure the internal consistency of the instruments. A Cronbach's alpha coefficient of 
0.76 was realized any items falling below 0.7 were eliminated to improve the reliability.

\subsection{Data analysis}

The survey data was analysed qualitatively and quantitatively using descriptive statistics in SPSS version 22 and results presented in tables and figures.

\section{Results and Discussion}

The respondents were asked various questions to try and establish the e-readiness status and the findings were organised according to the model developed by [7] and were as follows:

\subsection{Psychological readiness}

Psychological readiness is key in determining the outcome of an e-learning project. If the implementers are not ready, then the project is most likely going to fail. To assess the psychological readiness, the pupils, teachers and head teachers were asked questions whose responses give indication of their psychological readiness to implement the DLP in Kisii County.

Most of the pupils, $77.7 \%$ indicated that they enjoyed school more since the introduction of the LDDs and $79.9 \%$ of them said that they enjoyed using the LDDs.

Table 1 gives the teachers responses on psychological readiness to DLP.

Table 1. Teachers Responses on psychological readiness to DLP

\begin{tabular}{|l|c|c|c|c|c|}
\hline \multicolumn{1}{|c|}{ Statement } & \multicolumn{5}{c|}{ Response (\%) } \\
\hline & $\boldsymbol{T D}$ & $\boldsymbol{D}$ & $\boldsymbol{N}$ & $\boldsymbol{A}$ & $\boldsymbol{T A}$ \\
\hline I enjoy using TDD & 17.4 & 39 & 8.2 & 31.2 & 3.2 \\
\hline I have adapted to the new DD environment & 16.4 & 41.0 & 11.8 & 27.5 & 3.3 \\
\hline I see high value in DLP for our pupils & 18.0 & 26.2 & 9.2 & 41.6 & 4.9 \\
\hline I feel DLP in primary schools is a waste of time & 35.7 & 42.3 & 5.2 & 12.8 & 3.9 \\
\hline Use of TDD consumes a lot of time for class preparation & 26.6 & 34.1 & 6.9 & 30.2 & 2.3 \\
\hline
\end{tabular}

$\mathrm{N}=302$

Table 2 gives the head teachers responses on psychological readiness to DLP.

Table 2. Head Teachers Responses on Psychological Readiness to DLP

\begin{tabular}{|l|c|c|c|c|c|}
\hline \multicolumn{1}{|c|}{ Statement } & \multicolumn{4}{c|}{ Response (\%) } \\
\hline & $\boldsymbol{T D}$ & $\boldsymbol{D}$ & $\boldsymbol{N}$ & $\boldsymbol{A}$ & $\boldsymbol{T A}$ \\
\hline There is poor attitude to DLP among teachers & 16.8 & 40.5 & 18.9 & 17.4 & 3.2 \\
\hline $\begin{array}{l}\text { There is poor attitude to DLP among members of the school } \\
\text { administration }\end{array}$ & 20.0 & 45.8 & 19.5 & 9.5 & 2.6 \\
\hline There is resistance to change among staff implementing DLP & 16.3 & 43.7 & 16.8 & 15.8 & 4.7 \\
\hline
\end{tabular}

$\mathrm{N}=249$ 
More than one half, $67.9 \%$ of the head teachers indicated that their employees willingly apply technology in their teaching.

Whereas $41.6 \%$ of the teachers feel that DLP is valuable for leaning, $42.3 \%$ feel that it is a waste of time with $30.2 \%$ reporting that the use of TDDs consumes time in lesson preparation. In conclusion teachers who are the final implementers of the programme are not psychologically ready to implement it.

The results however indicate that the head teachers and the pupils are positive about the DLP and that they are psychologically ready to implement the use of the digital devices.

\subsection{Sociological readiness}

The interactions among members implementing DLP is also a great contributor to the success of the programme. Responses of the pupils, teachers, and head teachers are indicators of the sociological readiness.

The study found out that $78.2 \%$ of the pupils agree that teachers are very supportive of DLP and that they assist them readily in using the LDDs.

Table 3 indicates the responses of the teachers on Sociological Readiness to DLP

Table 3. Teachers Responses on Sociological Readiness to DLP

\begin{tabular}{|l|c|c|c|c|c|}
\hline \multicolumn{1}{|c|}{ Statement } & \multicolumn{4}{c|}{ Response (\%) } \\
\hline & $\boldsymbol{T D}$ & $\boldsymbol{D}$ & $\boldsymbol{N}$ & $\boldsymbol{A}$ & $\boldsymbol{T A}$ \\
\hline $\begin{array}{l}\text { Other teachers have shown interest in the use of the Digital } \\
\text { Devices }\end{array}$ & 17.7 & 38.4 & 11.1 & 25.2 & 7.5 \\
\hline Other teachers in the school are very supportive of the DLP & 16.4 & 26.9 & 8.2 & 40.0 & 8.5 \\
\hline
\end{tabular}

$\mathrm{N}=302$

A majority, $85.3 \%$ of the head teachers indicated that most of the teachers implementing DLP are happy with and supportive of the programme.

The study concludes generally on the sociological readiness of the implementers of DLP that teachers, pupils and head teachers are all supportive of one another in ensuring the success of the programme. The study however found out that $38.4 \%$ of the teachers have no interest in the use of the digital devices.

\subsection{Environmental readiness}

The environment inside and outside the schools where DLP is being implemented is vital. It will impact positively or negatively on the success of the programme being implemented.

Table 4 gives the factors as indicated by the teachers. 
Table 4. Teachers responses on environmental readiness

\begin{tabular}{|l|l|l|l|l|l|}
\hline \multicolumn{1}{|c|}{ Statement } & \multicolumn{4}{c|}{ Response (\%) } \\
\hline & \multicolumn{1}{|c|}{$\boldsymbol{T D}$} & \multicolumn{1}{c|}{$\boldsymbol{D}$} & \multicolumn{1}{|c|}{$\boldsymbol{N}$} & \multicolumn{1}{|c|}{$\boldsymbol{A}$} & \multicolumn{1}{|c|}{ TA } \\
\hline Parents of the school support DLP & 16.7 & 30.2 & 8.5 & 37 & 7.5 \\
\hline Teachers not involved in DLP are supportive of the project & 35.4 & 5.9 & 22.3 & 20.7 & 15.7 \\
\hline
\end{tabular}

\section{$\mathbf{N}=302$}

The head teachers also responded to questions relating to environmental forces impacting on the implementation of DLP as shown in Table 5 below.

Table 5. Head teachers responses on environmental readiness

\begin{tabular}{|l|c|c|}
\hline \multicolumn{1}{|c|}{ Statement } & \multicolumn{1}{c|}{ Response (\%) } \\
\hline & Yes & No \\
\hline We have ICT support staff linked to DLP & 46.8 & 50.0 \\
\hline DLP devices are maintained by our own staff & 78.4 & 19.5 \\
\hline There is enough security for the devices & 12.6 & 82.6 \\
\hline We have reliable power connection & 71.1 & 18 \\
\hline There is political influence that is a barrier to the DLP adoption & 12 & 70 \\
\hline
\end{tabular}

\section{$\mathbf{N}=\mathbf{3 0 2}$}

There seems to be fairly good support, $44.5 \%$ for the DLP from parents and the community. Teachers not involved with DLP are only $36.4 \%$ supportive of the programme.

\subsection{Human Resource readiness}

The human support systems design before implementation of an e-learning venture are very important in the success of the outcome. A majority, $72.6 \%$ of the teachers complained of not having technical support for the DLP within the schools. It takes long for the technical personnel from the county ICT office in charge of the programme to reach all schools in need. This means that maintenance takes long to be done. Measures need to be put in place to ensure timely maintenance for optimum results to be achieved by the programme.

\subsection{Financial readiness}

The financial support of an e-learning venture ensures that daily challenges faced can be sorted in time to allow smooth continuity of the programme. Most of the head teachers $68.9 \%$ indicated that they do not have a budget for the DLP and it is very difficult to support the teachers implementing the programme and meet daily needs that arise that impact on the programme continuity. There should be established a support fund to help schools cope with challenges that crop up from time to time. 


\subsection{Technological skill readiness}

Technological skill is essential for the use of the DLP devices. Technological skill aptitude of the respondents was assessed and the results recorded.

Most of the pupils, $60.2 \%$ said they have used a smartphone with $38.9 \%$ using it daily, $33.2 \%$ weekly and $25.1 \%$ monthly. Only $2.8 \%$ said they have never used a smartphone. Most, $82.3 \%$ of those who use a smartphone said that they use it to play games. On average $43 \%$ of the pupils said they know about Internet, Twitter, WhatsApp, Email and Google.

Majority, $76.1 \%$ of the teachers had used a smartphone within the past one month and $23.9 \%$ had used a tablet.

The teachers' responses on ICT device used in the past month are as shown in table 6.

Table 6. Teacher Responses on ICT Device Use in the Past One Month

\begin{tabular}{|l|l|l|}
\hline \multicolumn{1}{|c|}{ Device Used } & \multicolumn{1}{c|}{ Frequency } & \multicolumn{1}{c|}{\begin{tabular}{c}
\multicolumn{1}{c|}{ Percentage } \\
$(\%)$
\end{tabular}} \\
\hline Desktop & 30 & 9.8 \\
\hline Laptop & 83 & 27.2 \\
\hline Tablet & 83 & 27.2 \\
\hline Smartphone & 232 & 76.1 \\
\hline
\end{tabular}

\section{$\mathbf{N}=302$}

A majority, $78.7 \%$ of the teachers indicated that they have access to internet.

Table 7 shows the devices used by the teachers to access internet.

Table 7. Teachers Mode of Internet Access

\begin{tabular}{|l|c|c|}
\hline \multicolumn{1}{|c|}{ Internet access mode } & Frequency & $\begin{array}{c}\text { Percentage } \\
\text { (\%) }\end{array}$ \\
\hline Smartphone & 227 & 74.4 \\
\hline Modem & 35 & 11.5 \\
\hline Cyber & 78 & 25.6 \\
\hline
\end{tabular}

$\mathbf{N}=302$

The teachers responded on internet applications used as shown in Table 8.

Table 8. Teachers Responses on Internet Application Used

\begin{tabular}{|l|c|c|}
\hline \multicolumn{1}{|c|}{ Internet application used } & Frequency & Percentage (\%) \\
\hline Google search & 163 & 53.4 \\
\hline Yahoo search & 64 & 21 \\
\hline Email & 76 & 24.9 \\
\hline Twitter & 37 & 12.1 \\
\hline WhatsApp & 203 & 66.6 \\
\hline Facebook & 141 & 46.2 \\
\hline
\end{tabular}

$\mathbf{N}=302$

The head teachers responses on device / programme used are as shown in tables 9. 
Table 9. Head Teacher Responses on ICT Device/Programme Use in the Past One Month

\begin{tabular}{|l|c|c|c|c|c|}
\hline \multicolumn{1}{|c|}{ Device/Programme Used } & \multicolumn{5}{c|}{ How Often (\%) } \\
\hline & Daily & Occasionally & Rarely & Hardly & Never \\
\hline Computer & 12.6 & 42.6 & 34.2 & 6.3 & 3.2 \\
\hline Internet & 41.6 & 14.7 & 8.9 & 19.5 & 6.3 \\
\hline Word Processor & 11.6 & 7.4 & 14.7 & 34.2 & 15.3 \\
\hline Spreadsheet & 1.6 & 6.8 & 10.5 & 37.4 & 21.6 \\
\hline Presentation software & 1.6 & 6.8 & 7.4 & 35.8 & 27.4 \\
\hline
\end{tabular}

\section{$\mathrm{N}=249$}

A high percentage, $93.7 \%$ of the head teachers said they have access to internet. The modes used to access internet are as in table 10 .

Table 10.

Head Teachers Mode of Internet Access

\begin{tabular}{|l|c|c|}
\hline \multicolumn{1}{|c|}{ Internet access mode } & Frequency & Percentage (\%) \\
\hline Smartphone & 167 & 87.9 \\
\hline Modem & 27 & 14.2 \\
\hline Cyber & 38 & 20 \\
\hline
\end{tabular}

\section{$\mathrm{N}=249$}

The head teachers responses on internet applications used are as shown in table 11.

Table 11. Head Teachers Responses on Internet Application used

\begin{tabular}{|l|c|c|}
\hline \multicolumn{1}{|c|}{ Internet application used } & Frequency & Percentage (\%) \\
\hline Google search & 130 & 68.4 \\
\hline Yahoo search & 42 & 22.1 \\
\hline Email & 79 & 41.6 \\
\hline Twitter & 19 & 10 \\
\hline WhatsApp & 154 & 81.1 \\
\hline Facebook & 79 & 41.6 \\
\hline
\end{tabular}

\section{$\mathrm{N}=249$}

The findings indicate that the pupils are technologically ready since majority $(60.2 \%)$ have used technology related to the LDDs. The teachers and head teachers are also technologically ready. the teachers however are more used to the smart phone and mostly use it for social media. There is need to motivate them to use laptops and desktops as much as possible in order to improve their skills for use of TDDs.

\subsection{Equipment readiness}

More than one half, $64.2 \%$ of the Head teachers said the LDDs are not sufficient for learning and $46.9 \%$ of them felt that the TDDs are fewer than required for effective teaching. There is therefore an acute shortage of the LDDs. 


\subsection{Content readiness}

The findings indicated a serious shortfall in the training content within the digital devices and urgent measures need to be undertaken to ensure that the content is up to date all the time.

\section{Conclusion}

E-learning readiness of an institution implementing e-learning is very important for the success of e-learning project. The DLP implementation in Kisii County still has drawbacks that are both internal and external to the schools implementing it. These drawbacks hamper the outcomes anticipated. The study clearly shows that the DLP implementation still has bottlenecks that need urgent redress. Teacher readiness on all fronts assessed is still wanting. The teachers' attitude is also not positive enough to warrant a smooth take off of the programme. The pupils however are happy with the programme and ready to learn. The head teachers are also positive and ready to provide the leadership needed to ensure the continual improvement of the programme.

\section{Recommendations}

The following recommendations are made following the findings of this study:

- The Teachers Service Commission (TSC) in liaison with the ICT Authority should programme for deliberate well planned training sessions for teachers on the importance of ICT in education and the use of DLP devices in teaching. The training should also encompass innovative strategies of using the digital devices.

- The authority in charge of the DLP should institute measures to ensure that teachers are trained and enabled to develop a positive attitude to the programme.

- The government should finance the programme to ensure security for the devices is beefed up. The financing should address regular training for the teachers implementing the programme.

- Repair and maintenance of the devices should also be given priority to ensure that all the devices are working.

- The government should each year provide enough LDDs by taking into cognizant the new enrolment in class 1 and 2.

- Support for schools implementing DLP should be beefed up especially on maintenance to avoid overworking the teachers. The security of the devices should also be improved.

- The KICD should put mechanisms in place to ensure that the content in the DLP digital devices are updated regularly and diversify the content to cater for all learning styles. 


\section{Acknowledgement}

We wish to acknowledge the National Research Fund (NRF) for having funded this research project.

\section{References}

[1] Aydın, C. H., \& Tasci, D., "Measuring Readiness for e-Learning: Reflections from an Emerging Country" Educational Technology \& Society, Vol. 8, no. 4, pp. 244-257, 2005

[2] Babbie, E., The basics of social research. $4^{\text {th }}$ ed. Belmont, California: Thompson Wadsworth, 2008

[3] Babbie, E \& Mouton, J., The practice of social research. Cape Town: Oxford University Press, 2004

[4] Bhattacharya, I., \& Sharma, K., "India in the knowledge economy -an electronic paradigm" International Journal of Educational Management, Vol. 21, no 6, pp. 543 -568, 2007.

[5] Borotis, S. \& Poulymenakou, A. "E-Learning Readiness Components: Key Issues to Consider Before Adopting e-Learning Interventions". In J. Nall \& R. Robson (Eds.), Proceedings of E-Learn 2004--World Conference on E-Learning in Corporate, Government, Healthcare, and Higher Education (pp. 1622-1629). Washington, DC, USA: Association for the Advancement of Computing in Education (AACE), 2004

[6] Broadley, T., "Enhancing Professional Learning for Rural Educators by Rethinking Connectedness" Australian and International Journal of Rural Education, Vol. 22, no. 1, pp. $85-105,2012$

[7] Chapnick, S. (2000). Are you ready for e-learning? Retrieved February 29, 2016 from http:// blog.uny.ac.id/nurhadi/files/2010/08/ are_you_ready_for_elearning.pdf

[8] Durrheim, K., "Research design" in Research in practice: applied methods for the social sciences, Terre Blanche, M, Durrheim, K \& Painter, D., Eds. Cape Town: University of Cape Town Press, 2009, pp- 30-40.

[9] Fowler, F. J., Survey Research Methods ( $3^{\text {rd }}$ ed.). Thousand Oaks, CA: SAGE, 2002

[10] Kaur, K. \& Abas, Z., "An Assessment of e-Learning Readiness at the Open University Malaysia" International Conference on Computers in Education (ICCE2004), Melbourne, Australia, 2004.

[11] Kennewell, S., Tanner, H., Jones, S. and Beauchamp, G. (2008) "Analysing the use of interactive technology to implement interactive teaching" Journal of Computer Assisted Learning, Vol. 24, no.1, pp.61-73, 2008. https://doi.org/10.1111/j.1365-2729.2007.00244.x

[12] Mioduser, D, Nachmias, R, Lahav, O \& Oren, A., "Web-based learning environments: current pedagogical and technological state" Journal of Research on Computing in Education, Vol. 33 no.1, pp. 55-76, 2000. https://doi.org/10.108 $\underline{0 / 08886504.2000 .10782300}$

[13] Mugenda, M. O. \& Mugenda, G.A., Research Methods: Quantitative and Qualitative Approaches. Nairobi: African Centre for Technology Studies, 2003

[14] Olatokun, W. M., \& Opesade, O. A., "An e-readiness assessment of Nigeria's Premier University (Part 1*)" International Journal of Education and Development using Information and Communication Technology (IJEDICT), Vol. 4 no.2, pp.16-46, 2008. 
[15] Saekow, A., \& Samson, D., "E-learning Readiness of Thailand's Universities Comparing to the USA's Cases" International Journal of e-Education, e-Business, e-Management and e-Learning, Vol. 1, no.2, pp.126 -131, 2011. https://doi.org/10.7763/ijeeee.2011.v1.20

[16] Trinidade, Armando Rocha et al. "Current developments and best practice in open and distance learning." (2000).

[17] Voogt, J., \& Knezek, G., International Handbook of Information Technology in Primary and Secondary Education. New York: Springer, 2008

\section{$9 \quad$ Authors}

Makworo E. Obwoge is a technology educationist, electrical and electronics engineering educator and the co-ordinator School of Engineering and Innovative Technology at Kisii University. He is also a member of the Institution of Engineering Technologists (IET).

Teresa K. Abuya is a computer scientist and chair lady of the department of computing sciences at Kisii University.

Nyakoe G. Morara is a mathematics educator and head of research department at Kisii National Polytechnic.

Article submitted 2019-11-30. Resubmitted 2020-01-30. Final acceptance 2020-02-17. Final version published as submitted by the authors. 